\title{
Vermengde leer: Innovering in die onderrig van Praktiese Teologie aan voorgraadse studente
}

\begin{tabular}{|c|c|}
\hline \multicolumn{2}{|l|}{$\begin{array}{l}\text { Author: } \\
\text { Ian A. Nell }{ }^{1}\end{array}$} \\
\hline \multicolumn{2}{|c|}{$\begin{array}{l}\text { Affiliation: } \\
{ }^{1} \text { Department of Practical } \\
\text { Theology, Stellenbosch } \\
\text { University, South Africa }\end{array}$} \\
\hline \multicolumn{2}{|c|}{$\begin{array}{l}\text { Note: } \\
\text { This is an edited version } \\
\text { of a paper delivered at the } \\
6 \text { th annual conference of } \\
\text { the Scholarship of Teaching } \\
\text { and Learning organised by } \\
\text { the Centre for Teaching and } \\
\text { Learning (CTL), Stellenbosch } \\
\text { on } 16-17 \text { May, Somerset } \\
\text { West. }\end{array}$} \\
\hline \multicolumn{2}{|c|}{$\begin{array}{l}\text { Correspondence to: } \\
\text { Ian Nell }\end{array}$} \\
\hline \multicolumn{2}{|c|}{$\begin{array}{l}\text { Email: } \\
\text { ianell@sun.ac.za }\end{array}$} \\
\hline \multicolumn{2}{|c|}{$\begin{array}{l}\text { Postal address: } \\
171 \text { Dorp Street, Faculty } \\
\text { of Theology, Stellenbosch } \\
\text { University, Stellenbosch } \\
7600 \text {, South Africa }\end{array}$} \\
\hline \multicolumn{2}{|c|}{$\begin{array}{l}\text { Dates: } \\
\text { Received: } 03 \text { Mar. } 2012 \\
\text { Accepted: } 02 \text { Sept. } 2012 \\
\text { Published: } 15 \text { Feb. } 2013\end{array}$} \\
\hline \multicolumn{2}{|c|}{$\begin{array}{l}\text { How to cite this article: } \\
\text { Nell, I.A., 2013, 'Vermengde } \\
\text { leer: Innovering in die } \\
\text { onderrig van Praktiese } \\
\text { Teologie aan voorgraadse } \\
\text { studente', HTS Teologiese } \\
\text { Studies/Theological Studies } \\
\text { 69(1), Art. \#1241, } 8 \text { pages. } \\
\text { http://dx.doi.org/10.4102/ } \\
\text { hts.v69i1.1241 }\end{array}$} \\
\hline \multicolumn{2}{|c|}{$\begin{array}{l}\text { Copyright: } \\
\text { (C) 2013. The Authors. } \\
\text { Licensee: AOSIS } \\
\text { OpenJournals. This work } \\
\text { is licensed under the } \\
\text { Creative Commons } \\
\text { Attribution License. }\end{array}$} \\
\hline \multicolumn{2}{|l|}{ Read online: } \\
\hline 口ifdn & $\begin{array}{l}\text { Scan this QR } \\
\text { code with your } \\
\text { smart phone or } \\
\text { mobile device } \\
\text { to read online. }\end{array}$ \\
\hline
\end{tabular}

Blended learning: Innovation in the teaching of practical theology to undergraduate students. Blended learning is becoming increasingly prevalent in the academic environment. This approach to learning was developed for various reasons, including the problem of information overloading and the need for integration of theory and praxis. Recent research indicates that changes in the brain necessary for success in the learning process are related to numerous factors like practical exercises, emotions and background factors while learning. The purpose of this research was to evaluate through empirical research the innovative use of blended learning by first-year students in practical theology. The results of two empirical surveys indicate a positive experience of a variety of forms of learning by the students. The results are interpreted with the aid of theoretical insights from the fields of pedagogy and practical theology. Four pedagogical strategies are discussed, all of which individually contribute to the learning process. This includes pedagogies of contextualisation, interpretation, formation and performance. In conclusion, a number of recommendations are made about the use of blended learning in practical-theological teaching. It is done by making use of a case study within a theodramatic approach to practical theology. The use of the film Son of Man is examined as example in the light of the envisaged outcomes for practical-theological teaching.

\section{Inleiding}

Die praktiese teologie is voortdurend 'onder rekonstruksie' (Stevenson-Moessner 2008:4). 'n Deel van hierdie sogenaamde voortgaande taak (work in progress) is die onderrig van die vakgebied aan voorgraadse studente. Hierdie studente neem deel aan 'n sogenaamde oorgangsrite (rite of passage) waarin akademiese geletterdheid een van die hoofdoelwitte is (Van Schalkwyk 2010:203). Akademiese geletterdheid word deur Ballard en Clancy (1988:8) beskryf as 'a compound of linguistic, conceptual and epistemological rules and norms of the acedeme' waar die student die vermoë ontwikkel 'to use written language to perform those functions required by the (University) culture in ways and at levels judged to be acceptable by the reader'.

Aangesien die praktiese teologie voortdurend onder rekonstruksie is, vra dit ook innovering in die onderrig oppad na akademiese geletterdheid. ' $n$ Verdere doelwit van die programme in praktiese teologie is om die studente deel te maak van 'n sogenaamde praktykgemeenskap (community of practice) (Wenger 2000:226) waarin sosiale vaardigheid en persoonlike ervaring deel van die leerproses is. Volgens Cummins (2000:62) word die studente se vaardigheidsveld vergroot wanneer meerdere geleenthede vir sosialisering en deelname aan 'n spesifieke diskoersgemeenskap geskep word. So raak die studente deel van hierdie nuwe gemeenskap of dissiplinegroep deur ' $n$ nuwe stel waardes aan te leer en nuwe identiteite te ontwikkel sonder dat ou identiteite prys gegee hoef te word.

Die navorsing wat in hierdie artikel beskryf word, lewer verslag oor ' $n$ gevallestudie waarin die innovering van ' $n$ bestaande program binne die BTh-graad aan die Universiteit van Stellenbosch met behulp van vermengde leer plaasgevind het. ${ }^{1}$ Die innovering hou verband met die probleem wat in die kurrikulum ondervind is waar slegs van een tipe leerervaring gebruik gemaak is. Hierdie ervaring is aangebied in die vorm van lesings in 'n klassituasie. Laasgenoemde hou weer verband met die verdere uitdaging om die teorie en praktyk in die onderrig van praktiese teologie aan nuwe studente in die vakgebied praktiese teologie te integreer.

\section{Innovering van leerervaring}

Innovering is ontwikkel in die vorm van vermengde leer deur die gebruik van Webstudie ${ }^{2}$, tutorhulp, diensleeraktiwiteite en verskillende assesseringsmetodes. Die hipotese is dat die

1.Vermengde leer is die Afrikaanse vertaling van "blended learing (BLE). Vermengde leer word toenemend in akademiese literatuur aangetref: 'Blended learning (BLE) is increasingly used in the world, especially in university degrees and it is based on integrating webbased learning and face-to-face (FTF) learning environments' (Yilmaz 2010:121).

2.Webstudie is die naam van die Universiteit Stellenbosch se webgebasseerde leerbestuurstelsel (Blackboard Vista 8). 
innovering nie alleen die studente se kompetensie vergroot om hulle akademiese geletterdheid te ontwikkel en hulle toegang tot die gemeenskap van diskoers te help kry nie, maar ook om hulle ervaring van die leersituasie positief te beïnvloed. Die veronderstelling is dat hoe beter die ervaring en gepaardgaande belewenis van die leerervaring hoe groter is die moontlikheid dat hulle gemotiveerd sal wees om kreatief aan die leerervaring deel te neem.

In dié verband vind ek ook aansluiting by die opvatting van Leibowitz, Van der Merwe en Van Schalkwyk (2009:4-5) wat met die vertrekpunt werk dat die sukses van die eerstejaarstudent tot 'n groot mate afhang van die student se bereidwilligheid om ook self verantwoordelikheid vir sy of haar welsyn te aanvaar en dus positief op andere en die gemeenskap se invloed te reageer.

Die probleem wat ondersoek word, naamlik onderrig deur middel van net een pedagogiese strategie in die vorm van lesings in ' $n$ klassituasie, is nie net eerstehands deur die navorser ervaar nie, maar vorm ook deel van die breër akademiese diskoers oor die onderrig van praktiese teologie (vgl. Osmer 2008:213). Dié innovering word verder deur meta-teoretiese skuiwe in die teologie en opvoedkunde genoodsaak.

Die problematiek kan saamgevat word in die verskuiwing vanaf 'n oordrewe fokus op 'n eendimensionele klem op die kognitief-teoretiese onderrig van die praktiese teologie na die skep van meerdere geleenthede vir sosialisering en deelname aan prakties-teologiese diskoerse deur die studente se sosiale vaardigheid en persoonlike ervaring te vergroot. Laasgenoemde lei ook tot 'n groter integrasie van teorie en praxis $^{3}$ soos wat in resente navorsing oor praktiese teologie aan die orde kom (vgl. Bass \& Dykstra 2008).

Die navorsingsvraag wat in die artikel aangespreek word, kan soos volg geformuleer word: Sou 'n groter integrasie van formele onderrig deur die gebruik van 'vermengde leer' in die vorm van toegang tot webstudie en tutorhulp, betrokkenheid by diensleeraktiwiteite en die gebruik van verskillende vorme van assessering tot verbeterde en meer geïntegreerde leerprosesse (uitkomste) in die onderrig van praktiese teologie aan voorgraadse studente kon lei?

Die struktuur van die artikel sien soos volg daar uit: Daar word eerstens kortliks gekyk na wat onder vermengde leer verstaan word. Daarna word die empiriese analise en resultate van 'n deel van 'n eerstejaarsmodule in die praktiese teologie aan die orde gestel. In 'n volgende afdeling sal die empiriese resultate aan die hand van vier pedagogiese strategieë geïnterpreteer word. In die laaste afdeling word enkele aanbevelings oor die gebruik van vermengde leer in prakties-teologiese onderrig gemaak deur 'n spesifieke gevallestudie binne ' $n$ teo-dramatiese benadering tot die praktiese teologie te analiseer. Die gebruik van die rolprent

3.Praxis word in die praktiese teologie as 'teorie-gelade praktyke' beskou en hou dus

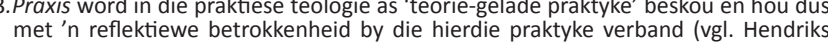
met 'n reflekt
2004:22).
Son of Man word vanuit die beoogde uitkomste vir praktiesteologiese onderrig as voorbeeld onder die soeklig geplaas. Hieruit sal enkele voorstelle volg wat tot ' $n$ verstelde praxis kan lei.

\section{Vermengde leer}

Alhoewel vermengde leer reeds langer as ' $n$ dekade in gebruik is, vind 'n mens dat dit nog nie algemeen in akademiese programme binne die teologiese vakgebied ingang gevind het nie. Laasgenoemde word onderstreep deur vir jou kollegas te vra wat hulle daaronder verstaan. Jy kan maklik van die volgende antwoorde verwag: 'Wat is dit? Nog nooit daarvan gehoor nie' of, 'Ek het al daarvan gehoor, maar het geen idee wat dit is nie' of 'Is dit nie e-leer met ander goed wat bygevoeg word nie?' of 'Is dit nie maar ou wyn in nuwe sakke nie?'.

Vermengde leer word soos volg deur Thorne (2003) geformuleer:

Blended learning is the most logical and natural evolution of our learning agenda. It suggests an elegant solution to the challenges of tailoring learning and development to the needs of individuals. It represents an opportunity to integrate the innovative and technological advances offered by online learning with the interaction and participation offered in the best of traditional learning. It can be supported and enhanced by using the wisdom and one-to-one contact of personal coaches. (bl. 16)

Hieruit is dit duidelik dat vermengde leer bestaan uit 'n mengsel van tradisionele vorme van leer in 'n klaskamersituasie (sogenaamde persoonlike kommunikasie) en multimedia-tegnologie wat webstudie, virtuele klaskamers, e-pos, aanlynaktiwiteite, diensleer- en joernaalaktiwiteite kan insluit.

Die belang en betekenis van hierdie vorm van leer is geleë in die potensiaal wat dit bied. Dit skep die geleentheid om die regte leerervarings deur die regte leerprosesse op die regte plekke vir elke individuele student moontlik te maak. Daarmee word die sogenaamde oorgangsritueel van akademiese geletterdheid en die toegang tot die gemeenskap van 'n nuwe akademiese diskoers beter gefasiliteer en vergemaklik. Volgens Frick (2010:16) is laasgenoemde uiteindelik ook ' $n$ belangrike voorwaarde vir studente om hulle eie akademiese onafhanklikheid te ontwikkel.

\section{Paradigmaskuiwe in prakties- teologiese onderrig}

Die kern van die teologiese teorievorming wat hierdie navorsing onderlê, hou verband met die wegbeweeg van 'n ensiklopediese benadering waarin die verskillende velde van die teologie in silo's hanteer word na 'n interdissiplinêre aanpak met' $n$ groter integrasie van teorie en praksis. Wanneer met 'n hermeneuties-retoriese vertrekpunt (Thiselton 2007:6) tot teologiese teorievorming en onderrig gewerk word, is die praktiese teologie nie 'n vakgebied wat eers aan die einde van die teologiese kurrikulum ter sprake kom nie, maar waar studente van hulle eerste jaar af van die akademiese diskoers in die vakdissipline deel raak. So word hulle nie net deel 
van 'n praktykgemeenskap nie, maar leer hulle ook hoe die integrasie van teorie en praktyk plaasvind (vgl. Bass 2010, Bonk 2009; Volf \& Bass 2001).

Aan die begin van 2010 is besluit om met die hulp van tutorhulp van die kant van $\mathrm{SOL}^{4}$ en deur die gebruik van vermengde leer innoverend aan die module Praktiese Teologie (PT) 114 aandag te skenk. PT-114 is 'n verpligte eerstejaarsmodule in praktiese teologie in die BTh-kursus waarin 'n inleiding tot die veld van die praktiese teologie gebied word. ${ }^{5}$ Een van die ander modules wat vir eerstejaarstudente verpligtend is, is Inligtingsvaardighede. ${ }^{6}$ Studente kla dikwels dat laasgenoemde 'n losstaande module is waarin sekere rekenaarvaardighede aangeleer word, maar sonder dat dit aan 'n spesifieke kursus of werksopdragte gekoppel word.? Vervolgens sal die empiriese studie en resultate aan die orde gestel word.

\section{Empiriese studie}

Die metodologie wat in die twee analises gebruik is, sou as 'n gemengde metode (Cameron et al. 2010; Osmer \& Schweitzer 2003) beskryf kon word. Denscombe (2008) beskryf die metode soos volg:

The mixed methods approach has emerged as a 'third paradigm' for social research. It has developed a platform of ideas and practices that are credible and distinctive and that mark the approach out as a viable alternative to quantitative and qualitative paradigms. (bl. 207)

Die eerste vraelys is deur die 2010-jaargroep voltooi en die tweede vraelys deur die 2011-klas. ${ }^{8}$ Beide vraelyste is met behulp van webstudie voorberei en voltooi. Die vraelys bestaan uit drie gedeeltes wat telkens 'n ander aspek van die leerervaring evalueer. Die drie afdelings sien soos volg daaruit:

- Afdeling 1: Dit behels klasbywoning, tyd bestee aan werkopdragte, die ervaring van opdragte en die ervaring van joernaalinskrywings. Die antwoorde op genoemde vrae het 'n positiewe respons van tussen $80 \%$ en $90 \%$ opgelewer. ${ }^{9}$ In 'n oop vraag oor studente se algemene indruk van die kursus gee ek net twee response:

4.SOL is die Sentrum vir Onderrig en Leer aan die Universiteit van Stellenbosch wat hulle aktiwiteite soos volg verduidelik: 'Ons visie is om 'n sentrum van uitnemendheid te wees wat kwaliteit onderrig en leer aan Stellenbosch Universiteit fasiliteer. Ons missie is om die instelling en dosente te ondersteun sodat die onderrig- en leerklimaat bevorder en die potensial vir studentesukses tot die maksimum verhoog kan word.' Vir meer besonderhede besoek http://www.sun. ac.za/sol

5.Die mees resente inleiding tot praktiese teologie binne die Suider-Afrikaanse konteks is die werk van Heyns en Pieterse (1990). Hierdie werk is reeds meer as konteks is die werk
twee dekades oud.

6.In die Jaarboek van Lettere en Sosiale Wetenskappe (2011:172) word hierdie module soos volg beskryf: 'Studie van en inoefening in informasiegebruik, die WWW en geselekteerde sagteware-programme op die gebiede van woordverwerking, aanbiedings, databasisse en sigblaaie in soverre dit vir kommunikasie- en informasiedoeleindes in die geesteswetenskappe noodsaaklik is.

7.Vergelyk in hierdie verband sommige van die response wat in die vraelys na vore gekom het.

8.Dr J.P. Bosman van SOL het gehelp met die opstel van die vraelys met behulp van Webstudie. Die goeie samewerking tussen die dosent, die tutor en $\mathrm{Dr}$ Bosman het 'n groot bydrae gelewer tot die suksesvolle afhandeling van die empiriese deel van die studie.

9.Die navorser het toestemming van die studente gekry om hul antwoorde anoniem as deel van die navorsing te gebruik met die oog op'n navorsingsverslag.
- 'Ek voel dat PT [praktiese teologie] 114 my gehelp het met die ontwikkeling van my teologiese woordeskat en dat dit my ook gehelp het om te sien hoe ander rasse en denominasies oor goed voel en daarna kyk... Die lees van bronne was baie interessant en ek voel dat dit baie van toepassing op ons eerstejaars was...' (Respondent 7, vroulik, 19 jaar)

- 'This module helped me to answer questions that I used to struggle with as to why the Church seems not to be effective in delivering its services. I am fairly certain that the content will help to make a difference in my ministry.' (Respondent 19, manlik, 21 jaar)

- Afdeling 2: Dit behels bywoning van PT 114 tutoriale, die waarde van tutoriale (webstudie, die gebruik van rekenaar, vaktydskrifte), vertroudheid met gebruik van biblioteek. Hier was die positiewe respons gemiddeld tussen $70 \%$ en $80 \%$ en is dit duidelik dat studente oor wisselende rekenaarvaardighede beskik. Die wat meer vertroud is met e-leer aktiwiteite (soos webstudie) vind die tutoriale na 'n tyd minder sinvol. In 'n oop vraag oor hoe die tutoriale aangepas kan word om studente beter te ondersteun, kry 'n mens in die response dieselfde tendens:

- 'Ek dink dit was sinvol, maar ek dink studente wat sukkel moet afsonderlik gehelp word...dit was goed, maar ek kan meeste van die goed self uitwerk...' (Respondent 11, manlik, 19 jaar)

- 'Maybe it should be conducted more than once a week. It was very useful and now I am able to search for information concerning my studies without any struggles.' (Respondent 14, vroulik, 19 jaar)

- Afdeling 3: Dit behels die beoordeling van rekenaaren webstudievaardigheid voor en na tutoriale, die gebruikersvriendelikheid van Webstudie en die bydrae van laasgenoemde tot sukses in studies. Hier was die gemiddelde respons weer tussen $70 \%$ en $80 \%$. In 'n oop vraag oor hoe Webstudie verder gebruik kan word om die studente in hulle studies te ondersteun, is die volgende antwoorde insiggewend:

- 'Omdat ek 'n beginner is, leer ek nog van die gebruik van Webstudie...ek is nie baie rekenaaringestel nie en dink dit is noodsaaklik...ek sou dit verkies as dit in meer vakke gebruik kon word...ek dink dit moet die enigste buite klas kommunikasiemiddel tussen dosent en student wees...' (Respondent 3, manlik, 19 jaar)

- 'I think it should be given more time in a week. I have learnt a lot in my Webstudie and it has also helped me with the struggles I had in my information skills module.' (Respondent 23, vroulik, 20 jaar).

Uit die resultate van die empiriese analise is dit duidelik dat vermengde leer in die sin van ' $n$ kombinasie van persoonlike onderrig in 'n klassituasie, tutorleiding met behulp van Webstudie, diensleer-aktiwiteite deur gesprekke met 'n mentor en blootstelling aan die praktyk van geloofsgemeenskappe opgevolg deur joernaalinskrywings en normale assesseringsprosesse alles deel is van 'n poging om die hipotese van hierdie studie innoverend te bevestig. 
Dit is naamlik: Hoe beter die ervaring en die gepaardgaande belewenis van die leerervaring is, hoe groter is die moontlikheid dat studente gemotiveerd sal wees om aan die leerervaring deel te neem en sodoende deel van 'n spesifieke diskoersgemeenskap te raak.

In die volgende afdeling word van vier verskillende pedagogiese strategieë as heuristiese instrumente gebruik gemaak om verder oor die belang van vermengde leer te reflekteer.

\section{Vier pedagogiese strategieë}

In aansluiting by die resultate van die empiriese studie kan die belang van die gebruik van vermengde leer in die onderrig van praktiese teologie aan eerstejaarstudente met behulp van die volgende vier pedagogiese strategieë verder verdiep en verklaar word. Ek maak gebruik van die omvattende studie van Foster et al. (2006:67-186) met die titel Educating Clergy: Teaching practices and pastoral imagination. Hulle bespreek in hulle werk vier verskillende strategieë, maar ek probeer om dit telkens met 'n eie toepassing op die gebruik van vermengde leer in die onderrig van praktiese teologie aan eerstejaarstudente aan te vul. ${ }^{10}$

\section{Kontekstuele pedagogieë}

Kontekstuele pedagogieë verwys na pedagogieë wat almal op die een of ander manier die sosiale gesitueerdheid van kennis en praktyke beklemtoon (Foster et al. 2006:127-155). In die geval van die onderrig van die praktiese teologie aan eerstejaars neem dit hulle situasie as nuwelinge (oorgangsritueel) in die akademiese diskoers van die praktiese teologie in ag. In die onderrig van die studente het dit eerstens ten doel om 'n bewussyn van hulle eie konteks by hulle te kweek. Die oogmerk is om hulle te help om kontekstueel oor die taak van die praktiese teologie na te dink. ${ }^{11}$

'n Tweede pedagogie fokus daarop om in studente die vermoë te ontwikkel om vanuit en met hulle verskillende kontekste konstruktief aan die ontmoeting deel te neem. Of dit die konteks van die klassituasie, die tutorhulp, die ontmoeting met ' $n$ mentor of die deelname aan aktiwiteite binne geloofsgemeenskappe is, dit gaan oor die kweek van 'n vermoë om verskillende kontekste te interpreteer.

'n Derde pedagogie is om die studente van die prosesse van sosiale en sistemiese transformasie van kontekste bewus te maak. Studente word van eie kulturele en ander vooroordele bewus gemaak en van die belang daarvan om sosiale analise vanuit verskillende perspektiewe te benader. Uit hierdie pedagogieë is dit duidelik dat studente se sosiale omstandighede ' $n$ groot invloed op hulle onderrig- en leersituasie uitoefen.

10.Vergelyk ook die werk van Cahalan, Hess en Miller-McLemore (2008) wat in die onderrig van die praktiese teologie van ses strategieë gebruik maak.

11.Vergelyk die werk van die Rooms Katolieke teoloog Schreiter (1985) wat ' $n$ groot deel van sy loopbaan aan die bestudering van konteks(te) bestee het.

\section{Interpretatiewe pedagogieë}

Binne die interpretasieteorieë bestaan daar konsensus dat daar vier verskillende realiteite in die interpretasieproses aangetref word. Dit sluit die volgende in: Die een of ander fenomeen wat geïnterpreteer moet word, die interpreteerder, die interaksie van die interpreteerder met dit wat geïnterpreteer word en die belang van 'n interpretasiegemeenskap. Al hierdie interpretasiepraktyke het een gemeenskaplike doel, naamlik om studente te help om krities te dink (Foster et al. 2006:70-99). In die lig van laasgenoemde kan ook verskillende interpretasiepedagogieë onderskei word. Dit sluit in:

- Interpretasie as 'n voortdurende dialoog waar verskillende vlakke van gesprek onderskei kan word. In die onderrigsituasie van eerstejaarstudente is dit veral die aanmoediging om aan verskillende gesprekke deel te neem. Dit is sluit in gesprekke in die klassituasie met behulp van die Sokratiese metode (vraag en antwoord), gesprekke met mentors in 'n diensleersituasie oor die werk wat in die klas behandel is en klasgesprekke in groepsverband.

- Interpretasie as die toepassing van tradisie. Die studente kom uit verskillende denominasionele tradisies. Elk van hierdie tradisies is lense wat die interpretasieproses kleur. 'n Bewussyn van en waardering vir hierdie tradisies help die studente om te verstaan hoedat die interpretasie van dieselfde aktiwiteit (soos byvoorbeeld die simbole van die doop of die nagmaal) tot verskillende toepassings van die tradisies aanleiding kan gee.

- Interpretasie deur die keuse van die 'regte metode'. Hier is dit belangrik om te verstaan dat die uitkoms van die module die metode bepaal. As daar eenstemmigheid bestaan dat dit gaan oor die ontwikkeling van die vermoë om krities te dink, dan is dit belangrik dat die metodologie ook die uitkoms moet dien. Sou die doel van kritiese denke kortliks as 'verstaan' beskryf kon word, moet die metode daartoe help dat studente die vermoë ontwikkel om sin te maak van tekste, situasies of kontekste en gebeure. Dit is dus die kapasiteit om tekste, situasies en verhoudings te lees, te analiseer en in ' $n$ denkraamwerk te integreer. Studente moet gehelp word om te verstaan dat hulle deel is van 'n voortgaande gesprek met die brondokumente, tradisie en huidige praktyke van geloofsgemeenskappe.

\section{Formatiewe pedagogieë}

Die onderskeidende kenmerk van formatiewe pedagogieë is dat dit probeer om 'n bydrae te lewer tot die vorming van kennis, houdings, vaardighede en gewoontes wat verband hou met die ontwikkeling van 'n professionele identiteit en met die praktyke, verbintenisse en die integriteit wat daarmee saamhang. Die doel waarna ' $n$ formatiewe pedagogie in die geval van religieuse leiers streef, het met betrokkenheid by die misterie van die menslike bestaan te make (Foster et al. 2006:99-126). Drie benaderings tot 'n pedagogie van formasie kan onderskei word. Dit sluit die volgende in:

- Die beoefening van die teenwoordigheid van God. Hierdie pedagogie hou daarmee verband studente bewus 
gemaak word van dit wat heilig en misterieus is, wat die menslike bewussyn deur tekste en die werklikheid self transendeer. Dit het dus te make met die transformering van die bewussyn en sluit in die vermoë om uit die perspektief van die 'Gans Andere', wat simbolies is van God, die heilige en die misterieuse, sin te maak van dinge.

- Heiligmaking as praktyk. Hierdie pedagogie sluit by laasgenoemde aan maar gaan ook verder 'to live on every word and gesture, taste, touch, smell, sound, and sight of the liturgies they celebrate with people' (Foster et al. 2006:104). Deur die inoefening van gewoontes en houdings wat met laasgenoemde verband hou, leer studente 'n manier van bestaan aan ('being functions') wat aan elkeen se bepaalde tradisie uniek is. Die pedagogiese intensie is dat hulle met die verloop van tyd die waarde van 'n bepaalde religieuse tradisie sal beliggaam in die manier waarop hulle dink, praat, handel en verhoudings ontwikkel.

- Die beoefening van religieuse leierskap. Hierdie pedagogie is die beoefening van die houdings en gewoontes van die vorige pedagogie binne spesifieke verantwoordelikhede en rolle wat met die praktyke van 'n religieuse beroep verband hou. Studente word gelei om sekere vaardighede te bemeester wat tot die vorm van leierskappatrone lei. Laasgenoemde hou verband met die manier waarop die tussenspel van institusionele prosesse en die mense wat daaraan deelneem, bemiddel word.

In elkeen van hierdie pedagogieë is dit duidelik dat 'n integrasie van hoof, hart en hand - dus van wie studente is, wat hulle doen en wat hulle weet - noodsaaklik is. Hierdie pedagogieë is daarom interafhanklik van mekaar om die kognitiewe vermoëns, emosionele ontwikkeling, praktiese vaardighede en identiteitsvorming van studente aan te help en in te oefen.

\section{Performatiewe pedagogieë}

Performatiewe taal voorsien die woordeskat om die openbare beoefening van die rolle en verantwoordelikhede wat met religieuse leierskap verband hou, te beskryf. Die verband tussen die optrede (lees 'performance') van die dosent in die klas en die uiteindelike professionele optrede van studente in die beroepswêreld staan nie los van mekaar nie. Pedagogieë van afrigting (coaching) wat 'n mens in handelinge soos die liturgie, prediking en onderrig vind, staan in noue verband met praktyke wat ons in die teater aantref en van waar performatiewe taal ook afgelei word.

Die term 'optrede' of 'opvoering' (performance) word dus in wye verband gebruik om te dui op 'n manier van dink en doen wat in die handelinge van mense se optrede, in die tot uitvoering bring of die in werking stel van gebeure tot openbaring kom. Hierdie opvoering vind binne 'n spesifieke tyd en omstandighede plaas wat voortdurend aan die skuif is, en in die opvoering vind 'n spesifieke beliggaming van die handelinge plaas (Foster et al. 2006:156-189).

McCall (in Foster et al. 2006:167) onderskei vier kenmerke van ' $n$ performatiewe pedagogie wat ook sinvol in die bespreking van hierdie spesifieke pedagogie gebruik kan word. Dit is naamlik:

1. die teks van die opvoering

2. die opvoerders (akteurs of karakters) en die gehoor

3. die plot of die wyse waarop die opvoering plaasvind

4. die telos of doel van die opvoering.

Die teks fokus die aandag op dit wat opgevoer moet word. In die opleiding van studente in die praktiese teologie is dit tipies die teks van die Bybel en die tradisie, maar dit kan ook die teks van 'n liturgie, 'n preek of 'n kategeseles wees. Dit kan op skrif, in die en of ander kunsvorm, deel van 'n mondelinge tradisie of ' $n$ ritueel wees. In die onderrig van die praktiese teologie is die doel hier om studente met die tekste van die religieuse tradisie in gesprek te laat tree terwyl hulle dit bestudeer. Terselfdertyd begin hulle ook leer hoe om dit in die praktyke van gebede, liturgiese handelinge, die versorging van mense en ander handelings modi in te oefen.

Die karakters en gehoor (dosent en studente) betree die verhoog van die klaskamer en dit wat hier afspeel dien reeds as 'n vorm van inoefening vir die opvoering van die plot wat in geloofsgemeenskappe plaasvind en waarvoor die studente voorberei word. As predikers, pastors, onderwysers en evangeliste sal hierdie studente op die verhoog van geloofsgemeenskappe hierdie aktiwiteite voortsit. Net soos in die klas sal die rolle voortdurende verwissel tussen akteur, regisseur en choreograaf om seker te maak die plot gaan voort.

Die plot (wyse en middel van opvoering) vra 'n sekere vaardigheid of vermoë van die akteurs. Dink byvoorbeeld aan die vaardighede wat nodig is om as liturg in 'n erediens voor te gaan: Dit behels spekte soos kleredrag, liggaamshouding, gebare, die gebruik van simbole en stemtoon, wat alles meewerk om op seker plekke en tye 'n heilige atmosfeer te voorsien. Al hierdie aspekte vorm deel van die plot as opvoering van 'n tradisie se praktyke.

Die telos of doel van die opvoering hou met die uiteindelike doel van die onderskeie pedagogieë in die praktiese teologie verband. Laasgenoemde het te make met verbeelding, houdings, vaardighede en kennis wat die verskillende akademiese dissiplines van die teologie aan mekaar bind en wat ook die kultuur en missie van 'n bepaalde instelling kleur.

Dit is duidelik dat die integrasie van die verskillende performatiewe pedagogieë deel uitmaak van 'n dinamiese interaksie waarin studente die geleentheid kry om uitdrukking en vorm te gee aan die kennis, houdings, vaardighede en perspektiewe wat hulle in die onderrigsituasie aanleer en inoefen. Vervolgens word na die gebruik van vermengde leer in prakties-teologiese onderrig gekyk deur die potensiaal wat 'n film soos Son of Man bied in die lig van die beoogde uitkomste van prakties-teologiese onderrig onder die soeklig te plaas. 


\section{Son of Man Inleiding}

Die film Son of Man is die verhaal van Jesus aan die hand van episodes uit die Nuwe Testament maar teen die agtergrond van hedendaagse Afrika. Jesus, gespeel deur Andile Kosi, beklee die hoofrol binne 'n gelaaide politieke konteks waar geweld aan die orde van die dag is. Maria, Jesus se moeder en gespeel deur Pauline Malefane, moet voor die geweld vlug vir haar lewe en skenk binne die omstandighede van 'n hedendaagse plakkerskamp aan Jesus geboorte. Jesus word groot en maak vir Hom 'n groepie volgelinge (dissipels) bymekaar. Sy boodskap is een van geweldlose verset.

Elkeen van die tonele en die onderskeie karakters is 'n herinterpretasie van grepe uit die evangelies vanuit 'n dramatologiese vertrekpunt. ${ }^{12}$ Onder die dissipels tel daar byvoorbeeld ' $n$ aantal vroue. Die rolprent het relatief min dialoog (alles in Xhosa), maar daar is eie aan Afrika baie musiek wat uit die hart uit kom. Van die aangrypendste momente in die rolprent is tonele van koorsang wat eer aan God bring. Die regisseur was Mark Donford-May (2006), wat in samewerking met die Dimphi Di Kopane teatergeselskap vir die improvisasie verantwoordelik was. Dit is dieselfde teatergeselskap wat 'U-Carmen', 'n weergawe van Bizet se opera, wat ook in die geheel in Xhosa gesing is, opgevoer het. ${ }^{13}$

\section{Kontekstuele insigte}

As ons die drie kontekstuele pedagogieë hierbo in gedagte hou, naamlik die kweek van 'n bewussyn van eie konteks, die konstruktiewe deelname aan en interaksie met verskillende kontekste en die sosiale en sistemiese transformasie van kontekste, raak dit duidelik hoekom die rolprent 'n goeie vertrekpunt vir die onderrig van die praktiese teologie bied. Die film word vroeg in die kursus vertoon. Die onderliggende epistemologie (kenteorie) wat as die 'videosfeer'14 beskryf kan word, sluit goed aan by meeste van die studente se basiese verwysingsraam.

Studente uit 'n hoofsaaklik wit agtergrond word onmiddellik gekonfronteer met 'n plakkerskampkonteks wat vir baie van hulle vreemd is, asook met 'n swart Messias wat konseptuele aanpassings vra. Die studente wat uit Afrika-kontekste kom, verstaan gewoonlik die Xhosa-dialoog in die film en help hulle klasmaats met die interpretasie van die dialoog. Hulle verstaan van die Xhosa-kultuur help veral ook met die herinterpretasie van sekere simboliese handelinge, soos die feit dat Jesus in die film volgens Xhosa-tradisie

$12 . ' n$ Nuwe belangstelling in drama vind ' $n$ mens in verskillende dissiplines binne die teologie. Kyk byvoorbeeld na: Nuwe Testament: Wright (1992); Anderson (1988). Kerkgeskiedenis: Quash (2005). Sistematiese Teologie: Brown (2008); Vanhoozer (2005); Von Balthasar (1998). Praktiese Teologie: Osmer (2005); Healy (2000); Childers en Schmit (2008).

13.Vir meer inligting oor die Dimphi Di Kopane teatergeselskap kan die volgende webwerf besoek word: http://rogerebert.suntimes.com/apps/pbcs.dll/article

14.Die filosoof, Johan Rossouw, gebruik die begrippe logosfeer, grafosfeer en videosfeer om die verskuiwing in die wyses waarop ons kommunikeer, te beskryf. In die logosfeer is dit die gesproke woord, in die grafosfeer is dit die geskrewe woord en veral die boekdrukkuns en in die videosfeer is dit die ontwikkeling van oudiovisuele media wat telkens in die sentrum staan (Pieterse 2005:412-413). besnydenis moet ondergaan, wat op 'n herinterpretasie van die dooppraktyk in die Nuwe Testamentiese verhale dui.

Dit is duidelik dat hier ' $n$ ryk bewussyn van kontekste geskep word wat nie alleen 'n geleentheid vir interaksie bied nie, maar gewis ook die potensiaal vir die sosiale en sistemiese transformasie van hierdie kontekste bevat.

\section{Interpretatiewe insigte}

In aansluiting by die kontekstuele insigte is al drie aspekte van die interpretatiewe pedagogieë ook by die interpretasie van die film aanwesig. Interpretasie as dialoog word aangewakker deur die gesprekke wat tussen die dosent en studente volg, asook tussen studente onderling oor die betekenis van die film. Die dialoog word verder versterk deurdat die toepassing van verskillende tradisies hier ter sprake is wat 'n ryk verskeidenheid kulturele en godsdienstige tradisies insluit. Die derde aspek, wat met die metode van interpretasie verband hou, skep die ideale geleentheid vir die ontwikkeling van kritiese denke waar die studente die vermoë ontwikkel om van tekste (die film as teks) en kontekste sin te maak. So word hulle kapasiteit om tekste en kontekste te analiseer en in 'n denkraamwerk te integreer, verder vergroot. ${ }^{15}$

Die werksopdragte wat verder hieruit voortvloei, help die student om sy of haar interpretasie-vaardighede nog beter te ontwikkel aangesien die analitiese aspek van wetenskaplike denke hierdeur aangewakker word en die student ook die geleentheid kry om sy of haar skryfvaardighede verder te ontwikkel. ${ }^{16}$

\section{Formatiewe insigte}

Ons het gesien dat formatiewe pedagogieë hoofsaaklik met betrokkenheid by die misterie van die menslike bestaan te make het. Dit sluit onder andere in die beoefening van die teenwoordigheid van God, heiligmaking as praktyk en die beoefening van religieuse leierskap. Die film is ten diepste 'n voorbeeld van wat Ganzevoort (2009) geleefde godsdiens (lived religion) noem en ons vind elk van genoemde aspekte in die film terug. Om slegs een voorbeeld te noem, daar is ' $n$ toneel waarin Jesus saam met sy dissipels in ' $n$ plakkershut brood breek en vloeistof uit blikbekers drink. Die 'sakramentele aard' van hierdie handeling sluit al drie genoemde formatiewe aspekte in.

Die studente se deelname aan die aktiwiteite van geloofsgemeenskappe (diensleer) en die koppeling daarvan aan die teoretiese insigte wat in die klas behandel word, waaronder ' $n$ bespreking van die sakramente, skep verskeie geleenthede vir geloofsvorming. Die feit dat die studente hulle vir een of ander vorm van geestelike leierskap voorberei, kweek die bewussyn dat hierdie aktiwiteite deur dissipline en geloofsgewoontes ingeoefen moet word.

15.Die werk van Freire (1972) en sy gedagtes oor ' $n$ kritiese pedagogie is hier van besondere belang.

16. Die hulp van tutors is in die verband van groot waarde, asook die skryflaboratorium wat ' $n$ belangrike diens lewer om die studente wat hiermee sukkel, te help. 


\section{Performatiewe insigte}

Performatiewe taal en kategorieë soos verhoog, teks, plot en karakters bied myns insiens 'n sinvolle dramatologiese verwysingsraamwerk vir die 'opvoering' van die handelinge wat in geleefde religie ter sprake is. Terselfdertyd is dit die kategorieë wat ook binne die filmwêreld veral deur filmkritici gebruik word. Faithful performances: Enacting Christian Tradition is die titel van Hart en Guthrie (2007) se boek waarmee hulle aandui dat die opvoering van die plot van die praktiese teologie met al die nuanses en intriges van die opvoering van die lewe te make het.

Dit is in dié verband wat die rolprent Son of Man soveel bied wat in die klassituasie met die studente bespreek kan word. Behalwe vir die optrede en karakterontwikkeling wat ons vind in die spel van Andile Kosi wat die hoofrol as Jesus vertolk, is daar die indrukwekkende spel van Pauline Malifane in die rol van Maria. ' $n$ Ander interessante karakter is die rol van Judas wat met 'n videokamera die gebeure rondom Jesus vaslê. Hier vind ons die herinterpretasie van die persoon wat Jesus verraai het en wat met sy kamera amper 'n soort speurderrol speel en daarmee interessante stof vir kritiese refleksie bied.

Die gebruik van terme soos verhoog, draaiboek (teks), plot en karakters voorsien 'n epistemologiese raamwerk wat nie alleen die teologiese grammatika verruim nie maar ook interessante moontlikhede vir herinterpretasie van die opvoering van die evangelie bied. ${ }^{17}$ Laasgenoemde bied selfs die moontlikheid om deur rollespel in die klas eie herinterpretasies van sekere tonele te maak..$^{18}$

\section{Gevolgtrekking}

Aan die begin van die artikel het ek daarna verwys dat die praktiese teologie voortdurend 'onder rekonstruksie' is, wat beteken dat die onderrig en refleksie oor metodes van onderrig 'n voortgaande proses is. Ek vertrou dat die argument van die artikel laasgenoemde bevestig. Daarom wil ek ook by wyse van samevatting graag terugkeer na die navorsingsvraag wat aan die begin gestel is, naamlik of 'n groter integrasie van formele onderrig deur die gebruik van 'vermengde leer' in die vorm van toegang tot Webstudie en tutorhulp, betrokkenheid by diensleeraktiwiteite en die gebruik van verskillende vorme van assessering tot verbeterde en meer geïntegreerde leerprosesse (as uitkomste) in die onderrig van praktiese teologie aan voorgraadse studente kan lei?

Die resultate van die navorsing dui daarop dat hierop bevestigend geantwoord kan word as daar in gedagte gehou word dat uitkomste gewoonlik verband hou met 'n beskrywing van die kennis, houdings en vaardighede wat deur'n sekere praktykgemeenskap as van waarde geag word en wat as noodsaaklik beskou word om sekere rolle te vervul (vgl. Gardner 1983:5).

17.Vergelyk die literatuur by voetnoot 12

18. Alhoewel nie deel van die eerstejaarsmodule nie het ek in ' $n$ module oor leierskap vir meestersgraadstudente gevra om self ' $n$ teks voor te berei en voor die klas op te voer. In die deelname, opvoering en kritiese refleksie na die tyd vind ' $n$ mens ' $n$ integrasie van verskeie van die pedagogieë wat bespreek is.
In die lig van laasgenoemde sou ons die innovering van die onderrig van die praktiese teologie aan voorgraadse studente aan die oorhoofse uitkoms van 'verstaan, insig of begrip' kon koppel. Verstaan word dan gebruik in die sin van die vermoë om kennis, houdings en vaardighede wat binne een konteks aangeleer is in nuwe kontekste en ander probleemsituasies te kan toepas of gebruik. Anders gestel, 'verstaan' is die vermoë om met onderskeiding en buigsaamheid te dink en op te tree met dit wat tot jou beskikking is (Osmer 2008:223).

In die lig van die vier pedagogiese strategieë wat bespreek is, sou die volgende uitkomste, voortvloeiend uit die oorhoofse uitkoms soos volg verwoord kon word: (1) die kweek van 'n bewussyn, analise en verstaan van verskillende kontekste en die konstruktiewe deelname aan en interaksie met hierdie kontekste; (2) die vermoё om te interpreteer binne 'n voortgaande dialoog en die toepassing van 'n ryke verskeidenheid tradisies uit 'n rykdom van kulture en kontekste; (3) die bereidwilligheid om gevorm te word deur die deelname aan en inoefening in verskillende geloofsdissiplines en praktyke wat met die misterie van die Goddelike te make het en (4) die gereedheid om deel te neem aan die opvoering van die handelinge wat in geleefde godsdiens ter sprake is en waar nodig ook in hierdie aktiwiteite leiding te neem.

Die belang en waarde van 'vermengde leer' word in die lig van laasgenoemde dus ten sterkste aangemoedig, maar dan is dit belangrik om in gedagte te hou dat innovering in die onderrig van die praktiese teologie aan voorgraadse studente nie maar bloot 'n saak is van die aanleer van 'n aantal tegnieke nie. Dit vra eerder wyse oordeel in spesifieke omstandighede en bo alles ' $n$ opregte belangstelling in die persoon van die student. Die bereidwilligheid om die pad te stap om studente te help groei, 'n nuwe self-verstaan te ontwikkel, te sien verander en te help om 'n realistiese prentiie van hulle sterk en swak punte te ontwikkel, is waarskynlik die belangrikste aspek van enige poging tot 'innovering' in die onderrig van die praktiese teologie. Dit vereis dus 'n kwaliteit van onderrig en mentorskap wat baie persoonlik is. Hoe om dit in ' $n$ klaskamer situasie reg te kry, veral as dit 'n groot klas is, bly een van die grootste uitdagings vir die innovering in die onderrig van praktiese teologie (Osmer 2008:223).

\section{Erkenning}

Finansiële ondersteuning deur die Fonds vir Innovasie in Leer en Onderrig (FINLO) het hierdie navorsing moontlik gemaak. Hiermee my dank en waardering teenoor Dr Brenda Leibowitz, direkteur van die Sentrum vir Onderrig en Leer (SOL) vir die finansiële steun.

\section{Mededingende belange}

Die outeur verklaar dat hy geen finansiële of persoonlike verbintenis het met enige party wat hom nadelig kon beïnvloed in die skryf van hierdie artikel.

\section{Literatuurverwysings}

Anderson, B.W., 1988, The unfolding drama of the Bible, 4th edn., Fortress Press, Minneapolis, MN. 
Ballard, B. \& Clanchy, J., 1988, 'Literacy in the university: An "anthropological" approach', in G.B. Taylor (ed.), Literacy by degrees, pp. 7-23, Open University approach, in G.B. Taylor
Press, Milton Keynes.

Bass, D.C., 2010, Practicing our faith: A way of life for a searching people, Jossey-Bass, San Francisco, CA.

Bass, D. \& Dykstra, C., 2008, 'Ways of life abundant', in Practical theology, theological education and Christian ministry, pp. 21-40, Eerdmans, Grand Rapids, MI.

Brown, D., 2008, God and mystery in words: Experience through metaphor and drama, Oxford University Press, Oxford. http://dx.doi.org/10.1093/acprof:0 so/9780199231836.001.0001

Bonk, C.J., 2009, The world is open: How web technology is revolutionizing education, 1st edn., Jossey-Bass, San Francisco, CA.

Cahalan, K., Hess, C.L. \& Miller-McLemore, B., 2008, 'Teaching Practical Theology: Introducing Six Perspectives', International Journal of Practical Theology, 12, 35-87, viewed 17 April 2011, from http://dx.doi.org/10.1515/IJPT.2008.4

Cameron, H., Bhatti, D., Duce, C., Seeney, J. \& Watkins, C., 2010, Talking about God in practice: Theological action, research and practical theology, SCM Press, London.

Childers, J. \& Schmit, C.J., 2008, Performance in preaching: Bringing the sermon to life Baker Academic, Grand Rapids, MI.

Cummins, J., 2000, Language, power and pedagogy: Bilingual children in the crossfire, Multilingual Matters, Clevedon.

Denscombe, M., 2008, 'Communities of Practice', Journal of Mixed Methods Research 2(3), 270, viewed 18 April 2011, from http://dx.doi. org/10.1177/1558689808316807

Donford-May, M., 2006, Son of Man, motion picture, Spier Films Production, Cape Town.

Foster, C.R., Dahill, L.E., Goleman, L.A. \& Tolentino, B.W., 2006, Educating clergy: Teaching practices and pastoral imagination, Jossey-Bass, San Francisco, CA.

Freire, P., 1972, Pedagogy of the oppressed, Penguin, Harmondsworth.

Frick, L. (2010), 'Creativity in doctoral education: Conceptualising the original contribution', in C. Nygaard, N. Courtney \& C. Holtham (eds.), Teaching Creativity - Creativity in Teaching, pp. 15-32, Libri Publishing, Faringdon.

Ganzevoort, R., 2009, 'Forks in the Road when Tracing the Sacred: Practical Theology as Hermeneutics of Lived Religion', unpublished presidential opening address of the 9th International Academy of Practical Theology, Chicago, July 30 - August 03 .

Gardner, H., 1983, Frames of mind: The theory of multiple intelligencies, Basic Books, New York, NY.

Hart, T. \& Guthrie, S.R., 2007, Faithful performances: Enacting Christian tradition, Ashgate, Aldershot.

Healy, N.M., 2000, Church, world and the Christian life: Practical-prophetic ecclesiology, Cambridge University Press, Cambridge. http://dx.doi.org/10.1017/ CBO9780511605857
Hendriks, H.J., 2004, Studying congregations in Africa, Lux-Verbi.BM, Wellington.

Jaarboek van Lettere en Sosiale Wetenskappe, 2011, Universiteit Stellenbosch, Stellenbosch.

Leibowitz, B., Van der Merwe, A. \& Van Schalkwyk, S., 2009, Focus on first-year success: Perspectives emerging from South-Africa and beyond, Stellenbosch, Sun Press.

Osmer, R.O., 2005, The teaching ministry of congregations, Westminster, Louisville, KY. Osmer, R., 2008, Practical theology: An introduction, Eerdmans, Grand Rapids, MN.

Osmer, R.R. \& Schweitzer, F., 2003, Religious education between modernization and globalization: New perspectives on the United States and Germany, Eerdmans, Grand Rapids, MN.

Pieterse, H.J.C., 2005, 'Die rol van Godskennis in die Ontmoetingsgebeure met God in die Prediking', In die Skriflig 39(3), 409-422. http://dx.doi.org/10.4102/ids. v39i3.395

Quash, B., 2005, Theology and the drama of history: Cambridge studies in Christian doctrine, Cambridge University Press, Cambridge. http://dx.doi.org/10.1017/ CBO9780511487811, PMid:15985231

Sentrum vir Onderrig en Leer (SOL), g.d., 'Visie en Missie', in Universiteit Stellenboch University, besigting geen datum, by http://www.sun.ac.za/sol

Schreiter, R.J., 1985, Constructing local theologies, Orbis Books, Maryknoll, NY.

Stevenson-Moessner, J., 2008, Prelude to practical theology: Variations on theory and practice, Abingdon Press, Nashville, TN.

Thiselton, A.C., 2007, The hermeneutics of doctrine, Eerdmans Publishing, Grand Rapids, MI. PMCid:2441648

Thorne, K., 2003, Blended learning: How to integrate online \& traditional learning, Kogan Page, London.

Vanhoozer, K.J., 2005, The drama of doctrine: A canonical-linguistic approach to Christian Theology, Westminster John Knox, Louisville, KY.

Van Schalkwyk, S., 2010, 'When the Teacher Becomes the Student: The Acquisition of Academic Literacy Revisted', Acta Academica, suppl. 1, 201-222.

Volf, M. \& Bass, D.C., 2001 Practicing theology: Beliefs and practices in Christian life, Eerdmans, Grand Rapids, MN.

Von Balthasar, H.U., 1998, Theo-drama: Theological dramatic theory: V: The last act, Ignatius Press, San Francisco, CA.

Wenger, E., 2000, 'Communities of Practice and Social Learning Systems', Organisation $7(2), 225-246$

Wright, N.T., 1992, The New Testament and the people of God, Fortress Press, Minneapolis, MN

Yilmaz, M.B. \& Orhan, F., 2010, 'Pre-service English Teachers in Blended Learning Environment in Respect to Their Learning Approaches', The Turkish Online Journa of Educational Technology 9(1), 157-164. 